\title{
Political conferences annual gathering or chance for debate?
}

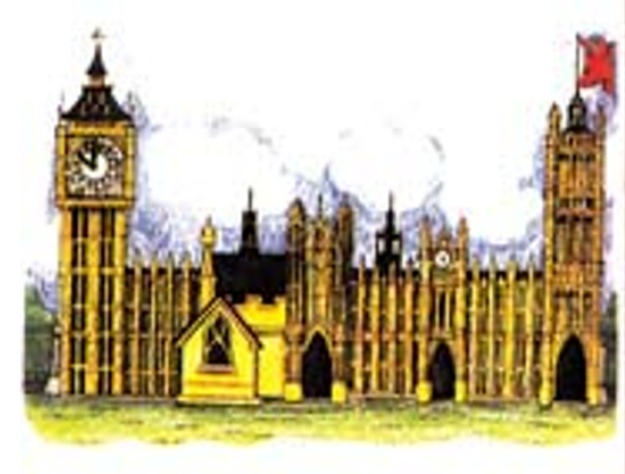

With the party conferences once again in full swing, BDA Press and

Parliamentary Officer Anjuli Veall takes a look at the highlights of the season

Over 10,000 people attend the party conferences each year with representatives from the world of commerce, the media, lobbying groups, as well as MPs, officers and members of the various political parties predominating.

So what prompts the party faithful to descend upon the nation's seaside resorts and spa towns for these political jamborees? Ostensibly, they are there to meet key decision makers, and to influence policy. For most parties, conference is technically the ultimate authority, deciding the policy framework from which future strategies will be drawn. It is within this context that many set-piece battles are fought both within the conference hall as well as in the fringe events.

Until recent years, the Labour Party conference was famed for hosting an inevitable showdown between the party's different factions. The resulting fracas undoubtedly made for interesting entertainment for spectators, but it also did much to dent Labour's image as a serious political force in the eyes of much of the electorate. As a result, much of the political wranglings that were once on full view, have now been swept aside in a sea of spin and perfect presentation.

Despite this, a few remnants from a more combative age live on: at the time of writing, much is being written about the prospect of a Blackpool debate during Labour Party conference on the US wardrive in the Middle East. The Prime Minister will certainly get a sense of how strong opposition to military action may be in his own party when delegates gather this coming week.

Commentators have wondered whether in private $\mathrm{Mr}$ Blair shares the view expressed by the man who was in the job exactly 100 years ago. The Conservative Arthur Balfour said he would rather take advice on policy from his valet than from the Tory Party Conference.
Conference may be an opportunity for policy wonks to air their latest views but it is also seen as an important opportunity for political parties to set out their stall to the wider world. This year, the Conservative Party's widely publicised overhaul of their annual conference in Bournemouth has given the pundits much to think about: party strategists believe that a daily change of colour and slogans on the main platform will help highlight the themes and the party's efforts to be seen as a more caring party of the vulnerable. Iain Duncan Smith is also continuing his policy of listening to outsiders who are likely to be critical of the party's past record.
Much media attention is often focused on the fringe precisely because the carefully stage managed main events no longer allow for the venting of impassioned viewpoints. Last year's Labour Party conference saw an eruption of fervent debate on the vexed issue of the private finance initiative prompted by the rallying of public sector workers by prominent trade unions.

This year, the BDA is planning on bringing dentistry into the political spotlight and will be present at all the main party conferences. At the Labour conference, a fringe meeting will be held. Entitled NHS dentistry: Alive and well or left to rot? the meeting will feature a prominent line-up of speakers including a Health Minister, BDA Chairman, John Renshaw as well as a representative from the Consumers' Association. With many important developments having taken

\section{'Commentators have wondered whether Mr Blair}

shares the view expressed by the man who was in the job exactly 100 years ago.... Arthur Balfour said he'd rather take advice on policy from his valet than from the Tory Party Conference.'

Those attending the conference include John Bird, founder of The Big Issue magazine for homeless people, and John Drake, chief executive of the Norwich YMCA. The party also hope that efforts to move away from television coverage of the older supporters will encourage more young people to become activists.

\section{The fringe}

The Party conferences are also famed for their fringe events which are not part of the main programme. These provide opportunities for a variety of interest groups - from non governmental organisations and trade unions to multinational corporations - to stage events designed to draw attention to whatever cause they happen to be pushing. place in the dental world in the past year, the meeting will be attempting to draw together a number of different themes.

The Government's proposals outlined in their recent Options for Change report, have provided one hook from which the event will draw inspiration, as has the inquiry into private dentistry by the Office of Fair Trading.

The Association has already brought the politics of the dental world to the Liberal Democrat conference last week when it sent representatives to Brighton. Similar plans are afoot for the Conservative Party conference in a week's time.

The BDA's Labour Party fringe event takes place in the Nelson Room at the Hilton Hotel, Blackpool, on Sunday 29 September at 5.30pm. All welcome. 